\title{
PRODUCTION CHARACTERISTICS OF SESAME GENOTYPES UNDER DIFFERENT STRATEGIES OF SALINE WATER APPLICATION ${ }^{1}$
}

\author{
GEOVANI SOARES DE LIMA ${ }^{2 *}$, CASSIANO NOGUEIRA DE LACERDA ${ }^{3}$, LAURIANE ALMEIDA DOS ANJOS \\ SOARES $^{2}$, HANS RAJ GHEYI ${ }^{3}$, RAILENE HÉRICA CARLOS ROCHA ARAÚJO ${ }^{2}$
}

\begin{abstract}
In semiarid areas, the scarcity of water with low salt concentration associated with irregular precipitation becomes a limiting factor to ensure agricultural production. In this context, the objective of this study was to evaluate the growth and production of sesame genotypes under different strategies of use of saline water. The experiment was conducted under protected environment conditions, using a randomized block design in a $6 \times 2$ factorial scheme, and the treatments consisted of six strategies for the use of saline water in the different stages of plant development $(\mathrm{SE}=$ irrigation with low-salinity water throughout the cultivation cycle; VE, FL, FR, VE/FL and VE/FR - respectively, irrigation with high-salinity water at the vegetative stage, flowering, fruiting, vegetative/flowering and vegetative/fruiting) and two sesame genotypes (BRS Seda and BRS Anahí), with 4 replicates. Irrigation with high-salinity water $\left(\mathrm{ECW}=2.7 \mathrm{dS} \mathrm{m}^{-1}\right)$ during the vegetative, flowering and fruiting stages did not compromise sesame production. There were reductions in sesame growth when irrigation with high-salinity water was continuously applied at the vegetative/flowering stages and in sesame production when it was applied during the vegetative/flowering and vegetative/fruiting stages. The greater growth of BRS Seda sesame plants resulted in an increase in the total number of fruits and in the total seed weight.
\end{abstract}

Keywords: Sesamum indicum L.. Salt stress. Water quality.

\section{CARACTERÍSTICAS PRODUTIVAS DE GENÓTIPOS DE GERGELIM SOB DIFERENTES ESTRATÉGIAS DE APLICAÇÃO DE ÁGUA SALINA}

RESUMO - Em áreas semiáridas, a escassez de água de baixa concentração de sais associado à irregularidade de precipitações, tornam-se um fator limitante para garantir a produção agrícola. Neste contexto, objetivou-se com este trabalho avaliar o crescimento e a produção de genótipos de gergelim sob diferentes estratégias de uso de águas salinas. O experimento foi desenvolvido sob condições de ambiente protegido, utilizando-se o delineamento de blocos casualizados em esquema fatorial $6 \times 2$, sendo os tratamentos constituídos de seis estratégias de uso de águas salinas aplicadas nos diferentes estádios de desenvolvimento das plantas (SE irrigação com água de baixa salinidade durante todo ciclo de cultivo; VE, FL, FR, VE/FL e VE/FR - irrigação com água de alta salinidade, respectivamente na fase vegetativa, floração, frutificação, vegetativa/floração e vegetativa/frutificação) e dois genótipos de gergelim (BRS Seda e BRS Anahí), com 4 repetições. A irrigação com água de elevada salinidade $\left(\mathrm{CEa}=2,7 \mathrm{dS} \mathrm{m}^{-1}\right)$ durante as fases vegetativa, floração e de frutificação, não comprometeu a produção do gergelim. Houve redução do crescimento quando a irrigação com água de elevada salinidade foi realizada na fase de floração e de forma contínua nas fases vegetativa/floração e na produção durante as fases vegetativa/floração e vegetativa/frutificação. O maior crescimento nas plantas de gergelim BRS Seda resultou em incremento no número total de frutos e na massa de sementes total.

Palavras-chave: Sesamum indicum L.. Estresse salino. Qualidade de água.

\footnotetext{
${ }^{*}$ Corresponding author

${ }^{1}$ Received for publication in 11/30/2019; accepted in 04/03/2020.

${ }^{2}$ Academic Unit of Agricultural Sciences, Center of Agrifood Science and Technology, Universidade Federal de Campina Grande, Pombal, PB, Brazil; geovani.soares@pq.cnpq.br - ORCID: 0000-0001-9960-1858, lauriane.soares@pq.cnpq.br - ORCID: 0000-0002-7689-9628, raileneherica.ufcg@gmail.com - ORCID: 0000-0001-8327-1591.

${ }^{3}$ Unit of Agricultural Engineering, Universidade Federal de Campina Grande, Campina Grande, PB, Brazil; cassianonogueiraagro@gmail.com - ORCID: 0000-0002-4132-1287, hans@pq.cnpq.br - ORCID: 0000-0002-1066-0315.
} 


\section{INTRODUCTION}

Sesame (Sesamum indicum L.) stands out for its high economic value, being cultivated for food and medicinal uses or employed in biodiesel production (JESUS et al., 2015). Its seeds contain oil with high nutritional quality due to the presence of unsaturated fatty acids, such as oleic and linoleic. It has great stability and resistance to rancidification, besides being used in the making of pasta, sweets, pies, paints, soaps, cosmetics and medicines (NOBRE et al., 2013; DIAS et al., 2017).

Brazilian sesame production is basically concentrated in the states of Mato Grosso, Mato Grosso do Sul, Pará and Ceará. In the 2017 season, the state of Mato Grosso occupied the first place with production of 3901 tons, in an area of 7551 hectares. In second place, Mato Grosso do Sul stood out with production of 200 tons, in an area of 202 hectares. The states of Pará and Ceará stood out in third and fourth places, with productions of 155 and 99 tons in planted areas of 170 and 264 hectares, respectively (IBGE, 2017).

The semiarid region of Northeastern Brazil has edaphoclimatic conditions conducive to sesame cultivation. However, the reduction in water availability due to agroclimatic imbalance imposes restrictions on agricultural crops, making irrigation an alternative to ensure food production in this region. However, the water used in irrigation, both surface water and subsurface water, mostly has high salt contents (SILVA et al., 2014; LIMA et al., 2016), becoming a limiting factor for production in this region.

Excess salts in water and/or soil affects plant growth and production due to the increase of osmotic pressure in the soil and interference in the absorption of nutrients by plants (MACHADO; SERRALHEIRO, 2017), resulting in deficiencies of $\mathrm{Ca}^{2+}, \mathrm{Mg}^{2+}, \mathrm{K}^{+}$and $\mathrm{NO}_{3}{ }^{-}$induced by excess of $\mathrm{Na}^{+}$ and $\mathrm{Cl}^{-}$, through ionic competition (MARSCHNER, 2011). However, plant responses to salt stress vary according to genotype, duration and time of exposure to salinity and, consequently, acclimatization mechanisms in some species, such as osmotic adjustment and control over ion absorption and translocation (ALVARENGA et al., 2019).

The cultivation strategies used to reduce the deleterious effects of excess salts on plants and soil include the choice of tolerant species or genotypes, use of water sources with high salt concentration at the stages of highest tolerance of crops, mixture of waters of different qualities and cyclic use of water sources with different salt concentrations (LACERDA et al., 2009).

Application of saline waters at varied stages of plant development stands out as an alternative for satisfactory production, under conditions of high risk of salinization (TERCEIRO NETO et al., 2014). In this context, Soares et al. (2018a) evaluated the physiological aspects and production of colored cotton genotypes under salt stress, during the different development stages, under low- and highsalinity conditions, and concluded that successive application of saline water at flowering and production formation caused a drastic reduction in the physiological aspects of the crop, with recovery of the plants after the stress was suspended.

When evaluating watermelon cultivation under different management strategies with saline water, Silva et al. (2019) found that the watermelon cv. Sugar Baby expressed greater sensitivity to salt stress at the vegetative and flowering stages, a situation that resulted in reduction of fruit size. Terceiro Neto et al. (2013) when evaluating the production and quality of melon fruits of the cultivars Sancho and Medellín, under management strategies of irrigation with saline water, concluded that irrigation using water with low salt concentration $\left(\mathrm{ECW}=0.61 \mathrm{dS} \mathrm{m}^{-1}\right)$, applied for two days, followed by irrigation with saline water (ECW $=4.78 \mathrm{dS} \mathrm{m}^{-1}$ ), applied for one day, enabled the commercial production of melon.

In view of the above, the objective of this study was to evaluate the growth and production of sesame genotypes as a function of strategies for the use of saline water under protected environment conditions.

\section{MATERIAL AND METHODS}

The experiment was carried out in a protected environment (greenhouse) of the Center of Science and Agri-food Technology - CCTA of the Federal University of Campina Grande - UFCG, located in the municipality of Pombal, Paraíba, PB, Brazil, at the geographic coordinates $6^{\circ} 47^{\prime} 20^{\prime}$ S latitude and $37^{\circ} 48^{\prime} 01^{\prime \prime}$ W longitude, at an altitude of $194 \mathrm{~m}$.

The experimental design was randomized blocks, in a $6 \times 2$ factorial arrangement, whose treatments resulted from the combination of six strategies for the use of saline water (SUS) applied at the different stages of plant development ( $\mathrm{SE}=$ irrigation with low-salinity water throughout the cultivation cycle - control; VE, FL, FR, VE/FL and VE/FR - respectively, irrigation with high-salinity water at the vegetative stage (15-31 days after sowing - DAS), at the flowering stage (32-56 DAS), at the fruiting stage (57-88 DAS), at the vegetative and flowering stages (15-56 DAS) and at the vegetative and fruiting stages (15-31 DAS and 56-88 DAS) and two genotypes (GEN) of sesame (BRS Seda and BRS Anahí), with 4 replicates. The plot was composed of one plant per pot, totaling fortyeight experimental units.

The levels of water salinity, expressed in terms of electrical conductivity of irrigation water (ECw), were 0.3 and $2.7 \mathrm{dS} \mathrm{m}^{-1}$ for waters with low and high salt concentrations, respectively. Regarding 
the stages of crop development, in the VE treatment the application of high-salinity water started upon the appearance of the first true leaf and ended upon the opening of the first flower; in the FL treatment, irrigation with high ECw began upon the opening of the first flower and extended until the formation of the fruits (capsule); in the FR treatment, saline water was applied from the appearance of the capsules until the end of harvest. The beginning of each stage occurred at the end of the previous one.

Seeds of the sesame genotypes BRS Seda and BRS Anahí were used in the present study. BRS Seda is a sesame cultivar with white seeds, which have higher commercial value, mainly for food and confectionery industries. It has potential for production of up to $2,500 \mathrm{~kg} \mathrm{ha}^{-1}$ of seeds, under ideal conditions of soil, water and crop management. The cultivar is tolerant to angular leaf spot, Cercospora leaf spot and charcoal rot diseases (EMBRAPA, 2007). BRS Anahí has dark green stem, medium size, 90-day cycle, unbranched growth habit, flowering at 39 days and three fruits per leaf axil. Its seeds have whitish color, average weight of $4.22 \mathrm{mg}$ and oil content ranging from 50 to $52 \%$. This cultivar is tolerant to charcoal rot, angular leaf spot and Cercospora leaf spot (EMBRAPA, 2015).

Plants were grown in $20-\mathrm{L}$ plastic pots adapted as lysimeters. Two holes were made at the base of each pot and connected to transparent drains with $4 \mathrm{~mm}$ in diameter. The tip of the drain inside the lysimeter was wrapped with a non-woven geotextile (Bidim OP 30) to avoid clogging by soil material. A container was placed below each drain to collect the drained water in order to estimate water consumption by plants. The pots were filled with Neossolo Regolítico (Psamments) of sandy clay loam texture, from the rural area of São Domingos, PB, whose chemical and physical characteristics (Table 1) were obtained according to the methodologies proposed by Teixeira et al. (2017).

Table 1. Chemical and physical characteristics of the soil used in the experiment.

\begin{tabular}{|c|c|c|c|c|c|c|c|c|}
\hline \multicolumn{9}{|c|}{ Chemical characteristics } \\
\hline $\left.\mathrm{pH} \mathrm{H}_{2} \mathrm{O}\right)$ & \multirow{2}{*}{$\begin{array}{l}\text { M.O. } \\
\text { g kg-1 }^{-1}\end{array}$} & \multirow{2}{*}{$\begin{array}{c}\mathrm{P} \\
\left(\mathrm{mg} \mathrm{kg}^{-1}\right) \\
\end{array}$} & $\mathrm{K}^{+}$ & $\mathrm{Na}^{+}$ & $\mathrm{Ca}^{2+}$ & $\mathrm{Mg}^{2+}$ & $\mathrm{Al}^{3+}$ & $\mathrm{Al}^{3+}+\mathrm{H}^{+}$ \\
\hline$(1: 2.5)$ & & & & \multicolumn{5}{|c|}{ 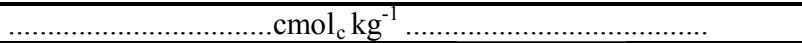 } \\
\hline 5.58 & 2.93 & 3.92 & 0.23 & 1.64 & 9.07 & 2.78 & 0.0 & 8.61 \\
\hline \multicolumn{9}{|c|}{ Chemical characteristics................ } \\
\hline \multirow{2}{*}{$\begin{array}{c}\mathrm{EC}_{\mathrm{se}} \\
\left(\mathrm{dS} \mathrm{m}^{-1}\right)\end{array}$} & \multirow{2}{*}{$\begin{array}{c}\text { CEC } \\
\mathrm{cmol}_{\mathrm{c}} \mathrm{kg}^{-1}\end{array}$} & \multirow{2}{*}{$\begin{array}{c}\text { SAR } \\
\left(\mathrm{mmol} \mathrm{L}^{-1}\right)^{0.5}\end{array}$} & \multirow{2}{*}{$\begin{array}{c}\text { ESP } \\
\%\end{array}$} & \multicolumn{3}{|c|}{ Size fraction $\left(\mathrm{g} \mathrm{kg}^{-1}\right)$} & \multicolumn{2}{|c|}{ Water content $\left(\right.$ dag kg $\left.{ }^{-1}\right)$} \\
\hline & & & & Sand & Silt & Clay & $33.42 \mathrm{kPa}^{1}$ & $1519.5 \mathrm{kPa}^{2}$ \\
\hline 2.15 & 22.33 & 0.67 & 7.34 & 572.7 & 100.7 & 326.6 & 25.91 & 12.96 \\
\hline
\end{tabular}

$\mathrm{pH}$ - Hydrogen potential, OM - Organic matter: Walkley-Black Wet Digestion; $\mathrm{Ca}^{2+}$ and $\mathrm{Mg}^{2+}$ extracted with $1 \mathrm{M} \mathrm{KCl}$ at $\mathrm{pH} 7.0 ; \mathrm{Na}^{+}$and $\mathrm{K}^{+}$extracted with $1 \mathrm{M} \mathrm{NH}_{4} \mathrm{OAc}$ at $\mathrm{pH} 7.0 ; \mathrm{Al}^{3+}+\mathrm{H}^{+}$extracted with $0.5 \mathrm{M} \mathrm{CaOAc}$ at $\mathrm{pH} 7.0 ; \mathrm{EC}_{\mathrm{se}^{-}}$ Electrical conductivity of the saturation extract; CEC - Cation exchange capacity; SAR -Sodium adsorption ratio of the saturation extract; ESP - Exchangeable sodium percentage; ${ }^{1}$ field capacity; ${ }^{2}$ permanent wilting point.

NPK fertilization was performed according to the recommendation of fertilization for pot experiments (NOVAIS; NEVES; BARROS, 1991), applying via fertigation, at 10-day intervals, 100, 150 and $300 \mathrm{mg} \mathrm{kg}^{-1}$ of soil of $\mathrm{N}, \mathrm{K}_{2} \mathrm{O}$ and $\mathrm{P}_{2} \mathrm{O}_{5}$, respectively. Urea and monoammonium phosphate were used as nitrogen source, whereas monoammonium phosphate and potassium chloride were used as phosphorus and potassium source. Fertilization with micronutrients was performed weekly, applied on the leaves, using solution $\left(1.0 \mathrm{~g} \mathrm{~L}^{-1}\right)$ of Ubyfol [(N (15\%); $\mathrm{P}_{2} \mathrm{O}_{5}(15 \%) ; \mathrm{K}_{2} \mathrm{O}$ (15\%); Ca (1\%); Mg (1.4\%); S (2.7\%); Zn (0.5\%); B $(0.05 \%) ; \mathrm{Fe}(0.5 \%) ; \mathrm{Mn}(0.05 \%) ; \mathrm{Cu}(0.5 \%) ; \mathrm{Mo}$ $(0.02 \%)]$.

The water used in the irrigation of the treatment of lowest salinity $\left(0.3 \mathrm{dS} \mathrm{m}^{-1}\right)$ came from the public supply system of Pombal - PB; the ECw level of $2.7 \mathrm{dS} \mathrm{m}^{-1}$ was prepared by dissolving $\mathrm{NaCl}$ in the supply water. The irrigation water with the highest salinity level was prepared considering the relationship between $\mathrm{ECw}$ and salt concentration, according to Richards (1954), as shown in (Equation 1):

$$
\mathrm{Q}\left(\mathrm{mmol}_{\mathrm{c}} \mathrm{L}^{-1}\right)=10 \times \mathrm{ECw}\left(\mathrm{dS} \mathrm{m} \mathrm{m}^{-1}\right) \ldots
$$

Where: Q = Quantity of salts to be applied $\left(\mathrm{mmol}_{\mathrm{c}} \mathrm{L}^{-1}\right)$; $\left(\mathrm{dS} \mathrm{m} \mathrm{m}^{-1}\right)$

$\mathrm{ECW}=$ Electrical conductivity of water

The ECw levels were checked with a conductivity meter (reading adjusted to temperature of $25^{\circ} \mathrm{C}$ ). After preparation, the water was stored in a $200-\mathrm{L}$ plastic container, one for each $\mathrm{ECw}$ level studied, properly protected to avoid evaporation, entry of rainwater and contamination with materials that could compromise its quality.

Sowing was performed by planting 15 sesame seeds per pot at $2 \mathrm{~cm}$ depth and, after seedling emergence, thinning was performed in two steps: when plants had two to three pairs of true leaves, at 15 and 25 DAS, respectively, leaving one plant per pot. After sowing, irrigation was performed daily at 
17:00 $\mathrm{h}$, applying in each plastic pot the volume corresponding to that obtained by the water balance. The water volume to be applied to the plants was determined by (Equation 2):

$$
\mathrm{VI}=\frac{(\mathrm{Vp}-\mathrm{Vd})}{(1-\mathrm{LF})}
$$

Where: VI $=$ Volume of water to be applied in the irrigation event $(\mathrm{mL}) ; \mathrm{Vp}=$ volume of water applied in the previous irrigation event $(\mathrm{mL}) ; \mathrm{Vd}=$ Volume of water drained $(\mathrm{mL})$ and $\mathrm{LF}=$ leaching fraction of 0.2 .

The growth of sesame plants was measured at 70 DAS, through plant height $(\mathrm{PH})$, stem diameter (SD), number of leaves (NL) and leaf area (LA). The yield was measured by the total number of fruits (TNF), total seed weight (TSW) and 1000-seed weight (1000SW). Plant height was measured using as reference the distance from the plant collar to the insertion of the apical meristem, stem diameter (SD) was measured at $2 \mathrm{~cm}$ from the plant collar, and the number of leaves (NL) was obtained by counting fully expanded leaves with minimum length of $3 \mathrm{~cm}$ in each plant. Leaf area was obtained by applying the Equation 3 proposed by Silva et al. (2002):

$$
\mathrm{LA}=\sum 0.3552 \times \mathrm{L}
$$

Where: LA - Total leaf area $\left(\mathrm{cm}^{2}\right)$ and L longitudinal length of the leaf $(\mathrm{cm})$.
The total number of fruits per plant was obtained by counting all fruits after harvest. The TSW was determined on a scale with $0.01 \mathrm{~g}$ accuracy. The 1000 -seed weight $(1000 \mathrm{SW})$ was determined according to rules for seed analysis (BRASIL, 2009), using eight replicates of 100 seeds from the 'pure seed' portion of each treatment, by individually weighing each sample on an analytical scale with $0.01 \mathrm{~g}$ accuracy and the result obtained was expressed in grams.

The obtained data were evaluated by analysis of variance by $F$ test. In cases of significance, ScottKnott clustering test $(p<0.05)$ was performed for the strategies of use of saline water and Tukey test $(p<0.05)$ was applied for sesame genotypes, using the statistical program SISVAR-ESAL version 5.6 (FERREIRA, 2019).

\section{RESULTS AND DISCUSSION}

According to the summary of analysis of variance (Table 2), there was a significant effect of SUS on the plant height $(\mathrm{PH})$, number of leaves (NL) and leaf area (LA) of sesame plants, at 70 DAS. The genotypes factor (GEN) had significant influence on SD, PH, NL and LA. The interaction between factors (SUS x GEN) did not significantly affect any of the sesame variables measured, indicating that the effects of the factors occurred independently at 70 DAS.

Table 2. Summary of the analysis of variance for stem diameter (SD - mm), plant height (PH - cm), number of leaves (NL) and leaf area $\left(\mathrm{LA}-\mathrm{cm}^{2}\right)$ of sesame genotypes cultivated under different strategies of use of saline water (SUS) at 70 days after sowing.

\begin{tabular}{lccccc}
\hline \multicolumn{1}{c}{ SV } & \multirow{2}{*}{ DF } & \multicolumn{3}{c}{ Mean squares } \\
\cline { 3 - 6 } & & SD & PH & NL & LA \\
\hline Strategies of use of saline water (SUS) & 5 & $8.99^{\text {ns }}$ & $1387.55^{*}$ & $569.38^{*}$ & $28216284.66^{* *}$ \\
Genotypes (GEN) & 1 & $198.41^{*}$ & $48133.33^{* *}$ & $3333.33^{*}$ & $21325240.76^{*}$ \\
Interaction (SUS x GEN) & 5 & $4.12^{\text {ns }}$ & $500.08^{\text {ns }}$ & $110.38^{\text {ns }}$ & $1013818.91^{\text {ns }}$ \\
Blocks & 3 & $15.33^{\text {ns }}$ & $38.94^{\text {ns }}$ & $550.22^{\text {ns }}$ & $6107375.69^{\text {ns }}$ \\
Residual & 33 & 9.41 & 308.17 & 162.08 & 2084928.41 \\
\hline CV (\%) & & 15.44 & 11.59 & 24.76 & 25.04 \\
LSD & & 19.86 & 26.54 & 19.25 & 5765.45 \\
\hline
\end{tabular}

SV - Source of variation; DF - degrees of freedom; CV (\%) - coefficient of variation; ${ }^{*}$ significant at 0.05 probability level; ${ }^{* *}$ significant at 0.01 probability level; ${ }^{n s}$ not significant; LSD - Least significant difference.

Plant height differed statistically when sesame plants were subjected to salt stress at the flowering (FL) and vegetative/flowering (VE/FL) stages in comparison to plants cultivated under the strategies SE, VE, FR and VE/FR (Figure 1A). However, there was no significant difference when low-salinity water was applied throughout the crop cycle and when high-salinity water was applied at the vegetative, fruiting and vegetative/fruiting stages. According to Costa et al. (2013), the negative effect of salt stress on plants is related to the intensity and duration of exposure to salts. The excess of salts in water and/or soil causes toxic effects on plants, due to the low capacity for osmotic adjustment of the crop or to the reduction in the total water potential caused by the increase in salt concentration (SOUSA et al., 2014). Guedes et al. (2015) found that irrigation using water with high salt concentration $\left(\mathrm{ECW}=3.5 \mathrm{dS} \mathrm{m}^{-1}\right)$ resulted in a reduction in the height of cherry tomato plants, cv. Carolina, in a protected environment.

As observed for PH (Figure 1A), the number of leaves (Figure 1B) of plants cultivated under water salinity of $2.7 \mathrm{dS} \mathrm{m}^{-1}$ at the flowering stage and vegetative/flowering stages successively was lower than those in plants that received water of 
lowest salinity level $\left(\mathrm{ECW}=0.3 \mathrm{dS} \mathrm{m}^{-1}\right)$ throughout the cycle and highest salinity level $(\mathrm{ECw}=2.7$ $\mathrm{dS} \mathrm{m}^{-1}$ ) at the vegetative (VE), fruiting (FR) and vegetative/fruiting (VE/FR) stages. By comparing the strategies for the use of saline water at the stages $\mathrm{SE}, \mathrm{VE}, \mathrm{FR}$ and VE/FR, it was observed that there was no significant difference among between them. The reduction in the number of leaves in plants cultivated under salt stress is an alternative to maintain low absorption of saline water (especially $\mathrm{Na}^{+}$and $\mathrm{Cl}^{-}$) (GUEDES et al., 2015). Unlike the results obtained in this study, Costa et al. (2013) in a study with the castor bean cv. BRS Energia, evaluating the use of irrigation strategies with saline water in order to identify the stage(s) of greater tolerance to salinity, observed that the number of leaves was not influenced by salt stress, regardless of the stage of crop development.
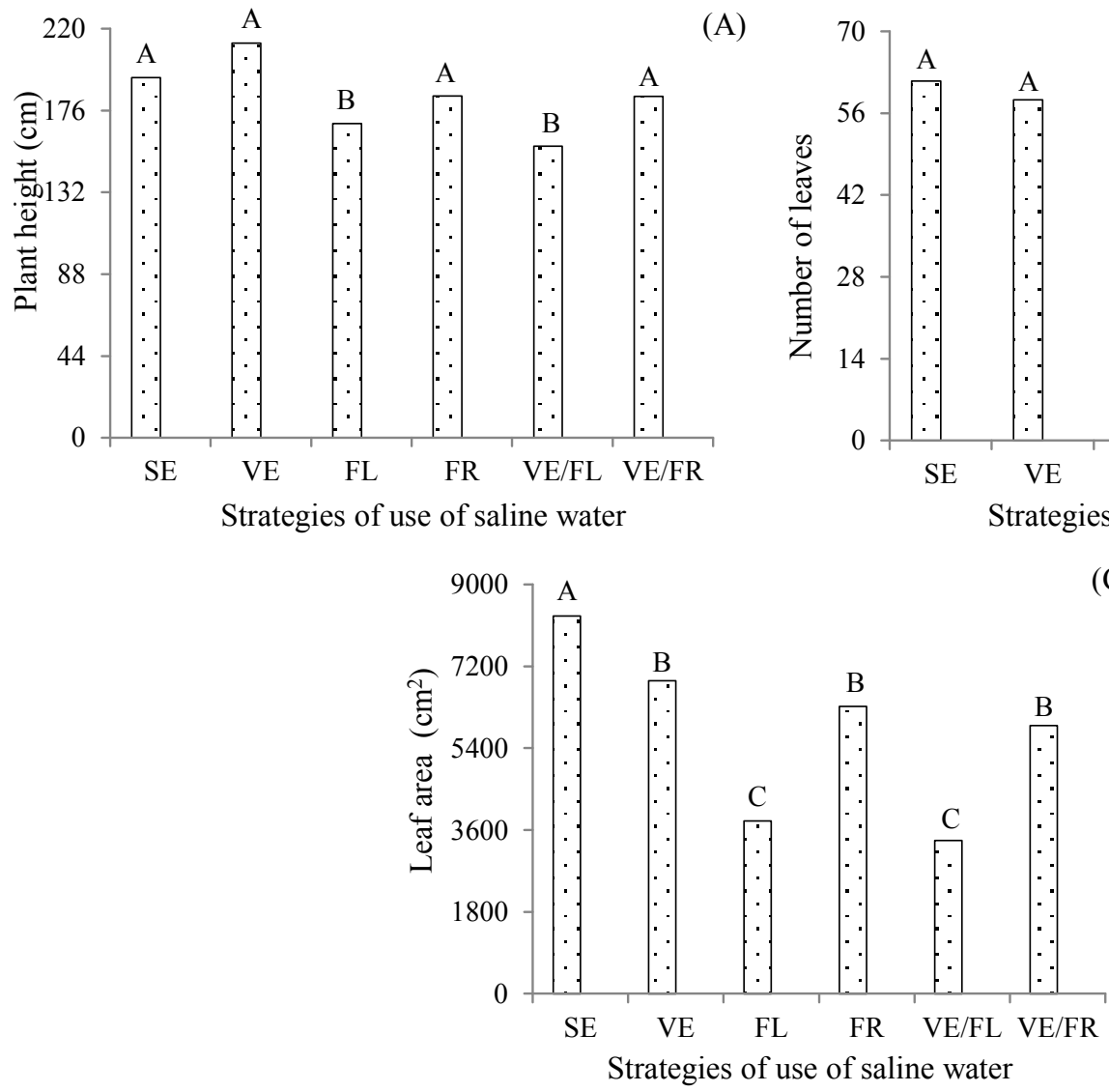

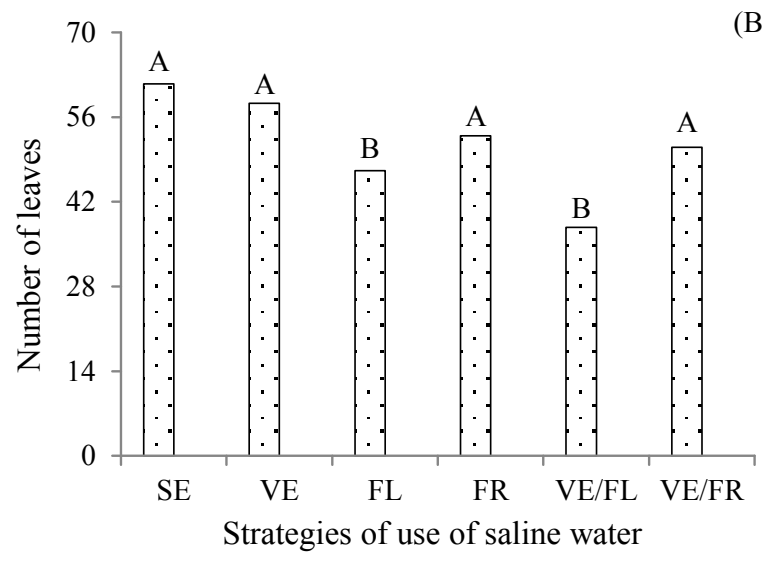

(C)

Means followed by different letters show significant difference between treatments by the Scott-Knott test $(p<0.05)$. SE irrigation with low-salinity water throughout the crop cycle; VE- salt stress only at the vegetative stage (15-31 DAS); FL salt stress at the flowering stage (32-56 DAS); FR - salt stress at the fruiting stage (57-88 DAS); VE/FL - salt stress at the vegetative and flowering stages (15-56 DAS); VE/FR - salt stress at the vegetative and fruiting stages (15-31 DAS and 5688 DAS).

Figure 1. Plant height (A), number of leaves (B) and leaf area (C) of sesame plants grown under different strategies of use of saline water, at 70 days after sowing.

The leaf area of sesame plants cultivated under low-salinity water $\left(\mathrm{ECW}=0.3 \mathrm{dS} \mathrm{\textrm {m } ^ { - 1 }}\right)$ throughout the cycle (SE) was statistically more than those of plants subjected to irrigation with highsalinity water at the vegetative (VE), flowering (FL) and fruiting (FR) stages and continuous application at the vegetative/flowering stages (VE/FL) and vegetative/fruiting stages (VE/FR) (Figure 1C). It can also be noted that there was no statistical difference between the strategies of irrigation with saline water $\left(\mathrm{ECW}=2.7 \mathrm{dS} \mathrm{m}^{-1}\right)$ at the stages VE, FR and VE/FR (Figure 1C). However, the LA values of plants cultivated under the treatments VE, FR and
VE/FR were higher than those plants subjected to irrigation using water with ECw of $2.7 \mathrm{dS} \mathrm{m}^{-1}$ at the FL and VE/FL stages successively. As observed for plant height (Figure 1A) and number of leaves (Figure 1B), the continuous use of saline water at the vegetative and flowering stages stands out with greater deleterious effect on sesame plants. The inhibition of growth in leaf area caused by excess of salts becomes more harmful when it affects cell growth and expansion of leaves, through the reduction in turgor pressure and cell wall extensibility, resulting in negative consequences in the net photosynthesis rate, hampering the 
physiological and biochemical processes of plants in general (SOUSA et al., 2014). Soares et al. (2018a), while evaluating the effects of different salinity management strategies on naturally colored cotton genotypes (BRS Rubi, BRS Topázio, BRS Safira), concluded that irrigation with saline water at the vegetative and flowering stages can be used in cotton cultivation with lower loss of growth.

According to the means comparison test for stem diameter (Figure 2A), plant height (Figure 2B) and number of leaves (Figure $2 \mathrm{C}$ ), the genotype BRS Seda stands out with higher growth compared to
BRS Anahí. The SD, PH and NL of the genotype BRS Seda were, on average, $4.06 \mathrm{~mm}, 63.84 \mathrm{~cm}$ and 16.67 leaves higher than those of BRS Anahí, respectively. The lower growth in BRS Anahí sesame plants compared to the genotype BRS Seda may be related to the variability of these genetic materials, since BRS Anahí is characterized by medium size and unbranched growth habit (EMBRAPA, 2015), whereas BRS Seda has a branched growth habit and medium size (EMBRAPA, 2007).
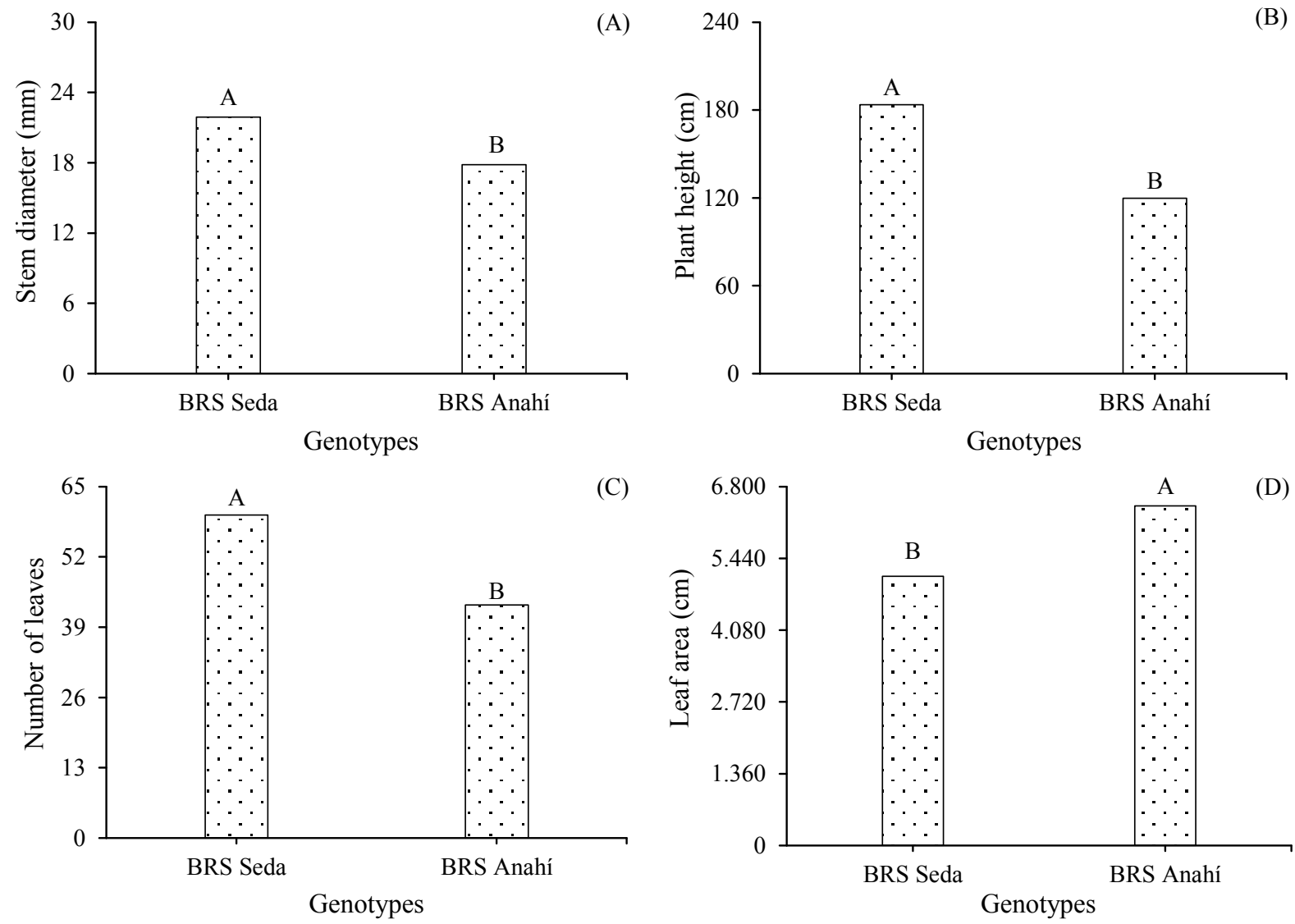

Means followed by different letters show significant difference between treatments by Tukey test $(\mathrm{p}<0.05)$.

Figure 2. Stem diameter (A), plant height (B), number of leaves (C) and leaf area (D) of sesame genotypes cultivated under different strategies of use of saline water, at 70 days after sowing.

Unlike stem diameter, plant height and number of leaves, the leaf area of BRS Anahí sesame plants was statistically higher than that of BRS Seda. There was a difference of $1333.08 \mathrm{~cm}^{2}$ between the LA of BRS Anahí and that of BRS Seda. The sesame genotypes found for cultivation usually have differences due to morphological characteristics (size, growth habit, seed color, among others) (EMBRAPA, 2015), so the reduction of growth in leaf area may be related to the inherent characteristics of each genotype.

According to the summary of the analysis of variance (Table 3), there was a significant effect $(p<0.05)$ of the strategies of use of saline water on the total number of fruits per plant (TNF) and on the total seed weight (TSW) of sesame plants. The genotype factor affected significantly TNF, TSW and $1000 \mathrm{SW}$. The interaction between factors (SUS $x$ GEN) did not significantly influence any of the variables analyzed at $88 \mathrm{DAS}$. 
Table 3. Summary of the analysis of variance for the total number of fruits per plant (TNF), total seed weight (TSW - g plant $^{-1}$ ) and 1000-seed weight $\left(1000 \mathrm{SW}-\right.$ g plant $\left.^{-1}\right)$ of sesame genotypes cultivated under strategies of use of saline water (SUS) at 88 days after sowing.

\begin{tabular}{lcccc}
\hline \multirow{2}{*}{ SV } & \multirow{2}{*}{ DF } & \multicolumn{3}{c}{ Mean squares } \\
\cline { 3 - 5 } & & TNF & TSW & $1000 \mathrm{SW}$ \\
\hline Strategies of use of saline water (SUS) & 5 & $6361.97^{*}$ & $125.45^{*}$ & $1.12^{\mathrm{ns}}$ \\
Genotypes (GEN) & 1 & $67125.52^{* *}$ & $726.18^{* *}$ & $2.50^{*}$ \\
Interaction (SUS x GEN) & 5 & $795.17^{\mathrm{ns}}$ & $31.41^{\mathrm{ns}}$ & $0.26^{\mathrm{ns}}$ \\
Blocks & 3 & $423.02^{\mathrm{ns}}$ & $13.78^{\mathrm{ns}}$ & $0.13^{\mathrm{ns}}$ \\
Residual & 33 & 1341.68 & 29.65 & 0.52 \\
\hline CV (\%) & & 31.27 & 36.06 & 21.45 \\
LSD & & 117.14 & 8.23 & 1.09 \\
\hline
\end{tabular}

SV - Source of variation; DF - degrees of freedom; CV (\%) - coefficient of variation; ${ }^{*}$ significant at 0.05 probability level; ${ }^{* *}$ significant at 0.01 probability level; ${ }^{\text {ns }}$ not significant; LSD - Least significant difference.

According to the means comparison test (Figure 3A), sesame plants grown under the strategies SE, VE, FL and FR obtained a total number of fruits per plant statistically higher than those subjected to irrigation with high-salinity water at $\mathrm{VE} / \mathrm{FL}$ and $\mathrm{VE} / \mathrm{FR}$ stages. Thus, it is clear that plants irrigated with high-salinity water at successive stages produced a less number of fruits compared to those that received high-salinity water only at one stage of development. The decrease in the total number of fruits in sesame plants occurs because of the reduction in the osmotic potential of the soil solution, inducing the reduction of water potential and consequently reducing the absorption of water and nutrients by plants, as well as their photosynthetic capacity, due to several factors, such as dehydration of cell membranes, ionic toxicity, reduction in $\mathrm{CO}_{2}$ supply, salinity-induced senescence and change in enzyme activity (TERCEIRO NETO et al., 2013).

Soares et al. (2018b), in a study evaluating the physiological aspects and the production of colored cotton genotypes under salt stress, during the different stages of plant development, concluded that the production of cotton lint is not compromised by the use of high-salinity water at the early stages of development of naturally colored cotton (BRS Rubi, BRS Topázio e BRS Safira).
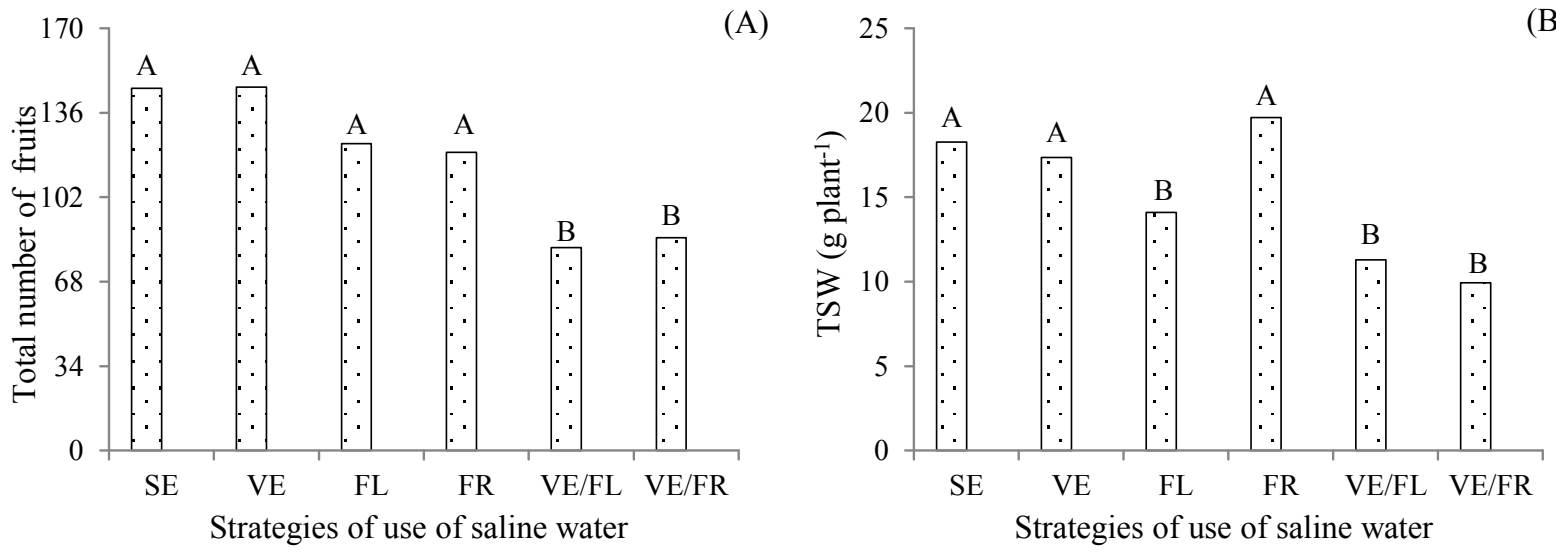

Means followed by different letters show significant difference between treatments by the Scott-Knott test $(\mathrm{p}<0.05)$. SE irrigation with low-salinity water throughout the crop cycle; VE - salt stress only at the vegetative stage (15-31 DAS); FLsalt stress at the flowering stage (32-56 DAS); FR - salt stress at the fruiting stage (57-88 DAS); VE/FL - salt stress at the vegetative and flowering stages (15-56 DAS); VE/FR - salt stress at the vegetative and fruiting stages (15-31 DAS and 5688 DAS).

Figure 3. Total number of fruits per plant - TNF (A) and total seed weight - TSW (B) of sesame plants grown under different strategies of use of saline water (SUS), at 88 days after sowing (DAS).

The total seed weight of sesame plants was also influenced by the saline water use strategies. According to the means comparison test (Figure 3B), plants grown under the strategies SE, VE and FR obtained the higher TSW $(18.26,17.34$ and
$19.70 \mathrm{~g} \mathrm{plant}^{-1}$, respectively), differing significantly only from those subjected to salt stress at the FL, $\mathrm{VE} / \mathrm{FL}$ and VE/FR stages. There is a more pronounced effect of salt stress on sesame plant production when saline water is applied continuously 
during two stages of development. Corroborating the results of this study, Costa et al. (2013) evaluated the use of saline water irrigation strategies on the growth and production of castor bean (BRS Energia) and concluded that the castor bean plants did not show different levels of tolerance to salinity according to the development stage, although they were hampered when the intensity and duration of salt stress increased.

The total number of fruits per plant (Figure 4A) and the total seed weight (Figure 4B) of sesame plants followed the same trend of the growth in $\mathrm{PH}$, $\mathrm{SD}$ and number of leaves. According to the means
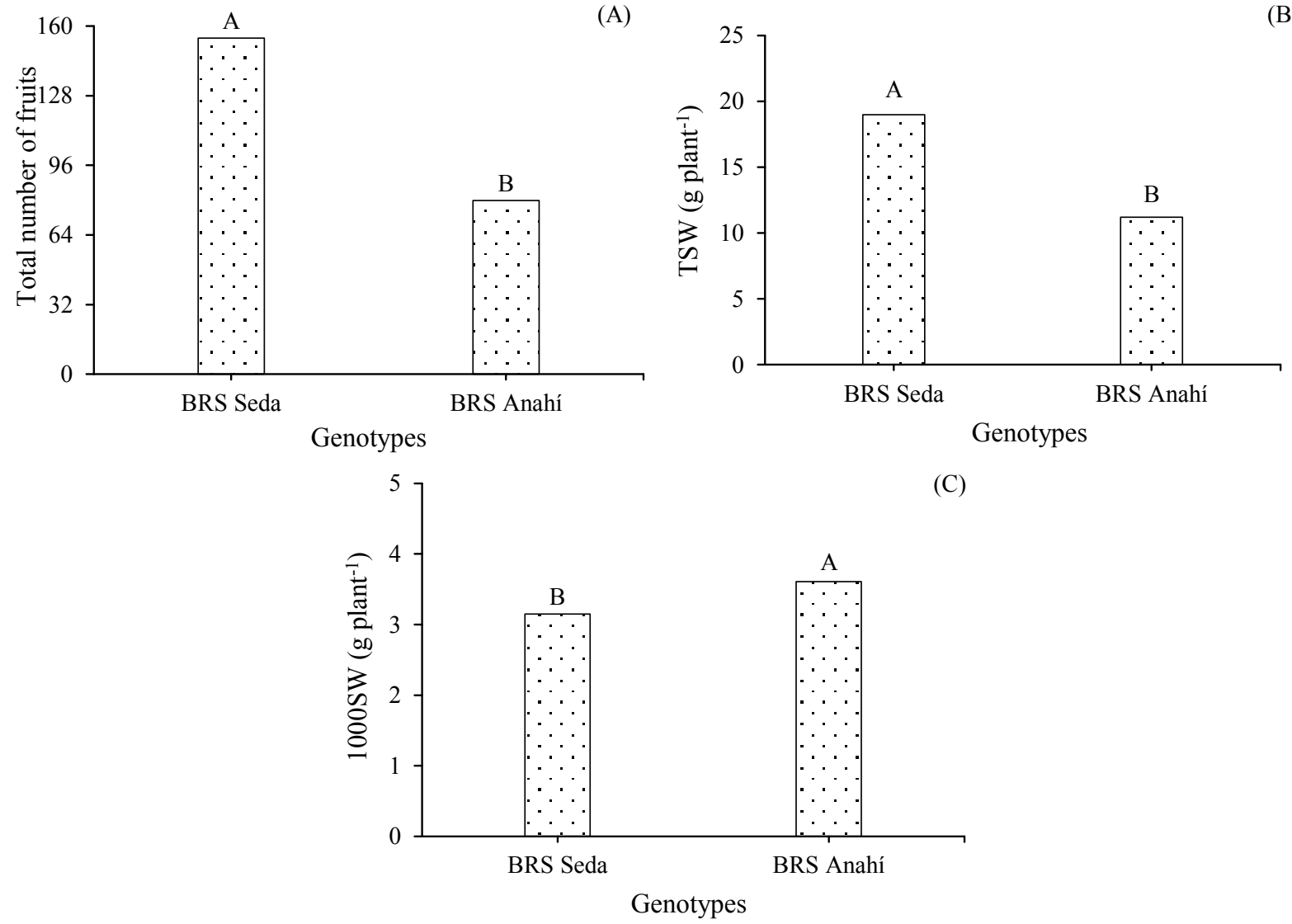

Means followed by different letters show significant difference between treatments by Tukey test $(\mathrm{p}<5 \%)$.

Figure 4. Total number of fruits per plant (A), total seed weight - TSW (B) and thousand-seed weight - 1000SW (C) of sesame genotypes cultivated under different strategies of use of saline water (SUS), at 88 days after sowing.

Regarding the 1000-seed weight of sesame plants (Figure 4C), the means comparison test shows that BRS Anahí obtained the higher values of 1000SW (3.61 $\mathrm{g} \mathrm{plant}^{-1}$ ), significantly differing from BRS Seda (3.15 g plant $\mathrm{g}^{-1}$ ). The 1000SW of BRS Anahí was $0.46 \mathrm{~g} \mathrm{plant}^{-1}$ higher than that of BRS Seda. Despite the reduction of 1000-seed weight in BRS Seda, the value obtained in this study is close to that recommended for this genotype, according to Embrapa (2007), which is equal to $3.22 \mathrm{~g}$, on average, for BRS Seda under normal conditions of soil and water, as well as adequate management. comparison test (Figure 4A and 4B), the genotype BRS Seda obtained higher TNF and TSW compared to BRS Anahí. BRS Seda, which produced the higher TNF and TSW, was also the one that stood out in terms of the growth variables, SD, PH and NL (Figure 2A, 2B and 2C). The higher production observed in the genotype BRS Seda, compared to BRS Anahí, may be a consequence of the high photosynthetic capacity of this genetic material under semiarid conditions, evidenced in the present study by the values of SD, PH and NL, which resulted in higher fruit production and seed weight.
However, for the genotype BRS Anahí, the value found in the present study (3.61 $\left.\mathrm{g} \mathrm{plant}^{-1}\right)$ is lesser than $4.22 \mathrm{~g} \mathrm{plant}^{-1}$, as highlighted by Embrapa (2015).

\section{CONCLUSIONS}

Irrigation with high-salinity water $(\mathrm{ECw}=2.7$ $\mathrm{dS} \mathrm{m}^{-1}$ ) during the vegetative, flowering and fruiting stages does not compromise the production of sesame genotypes BRS Seda and BRS Anahí. 
However, there are reductions in growth when irrigation with high-salinity water is carried out in the flowering stage and continuously at the vegetative/flowering stages and in production during the vegetative/flowering and vegetative/fruiting stages.

The greater growth of BRS Seda sesame plants increases the total number of fruits and the total seed weight.

There is no significant interactive effect of the factors saline water use strategies and genotypes for any of the growth variables and production components analyzed, at 70 and 88 days after sowing.

\section{REFERENCES}

ALVARENGA, C. F. S. et al. Morfofisiologia de aceroleira irrigada com águas salinas sob combinações de doses de nitrogênio e potássio. Revista de Ciências Agrárias, 42: 194-205, 2019.

BRASIL. Ministério da Agricultura e Reforma Agrária. Regras para análise de sementes. Brasília, DF: Mapa/ACS, 2009. 399 p.

COSTA, M. E. et al. Estratégias de irrigação com água salina na mamoneira. Revista Ciência Agronômica, 44: 34-43, 2013.

DIAS, A. S. et al. Emergence, growth and production of sesame under salt stress and proportions of nitrate and ammonium. Revista Caatinga, 30: 458-467, 2017.

EMPRESA BRASILEIRA DE PESQUISA AGROPECUÁRIA - EMBRAPA. Gergelim, BRS Seda. 1. ed. Campina Grande, PB: Embrapa Algodão, 2007. 2 p.

EMPRESA BRASILEIRA DE PESQUISA AGROPECUÁRIA - EMBRAPA. Gergelim, BRS Anahí. 1 ed. Campina Grande, PB: Embrapa Algodão, 2015. 2 p.

FERREIRA, D. F. SISVAR: A computer analysis system to fixed effects split plot type designs. Revista Brasileira de Biometria, 37: 529-535, 2019.

GUEDES, R. A. A. et al. Estratégias de irrigação com água salina no tomateiro cereja em ambiente protegido. Revista Brasileira de Engenharia Agrícola e Ambiental, 19: 913-919, 2015.

INSTITUTO BRASILEIRO DE GEOGRAFIA E ESTATÍSTICA - IBGE. Censo Agropecuário, 2017 $<$ Disponível em: https://sidra.ibge.gov.br/Busca? q=GERGELIM $>$. Acesso em: 03 mar. 2020.
JESUS, L. L. et al. Teste de tetrazólio para sementes de Sesamum indicum. Revista de Ciências Agrárias, 38: 422-428, 2015.

LACERDA, C. F. et al. Eficiência de utilização de água e nutrientes em plantas de feijão-de-corda irrigadas com água salina em diferentes estádios de desenvolvimento. Engenharia Agrícola, 29: 221230,2009

LIMA, G. S. de et al. Castor bean production and chemical attributes of soil irrigated with water with various cationic composition. Revista Caatinga, 29: 54-65, 2016.

MACHADO, R. M. A.; SERRALHEIRO, R. P. Soil salinity: Effect on vegetable crop growth: Management practices to prevent and mitigate soil salinization. Horticulturae, 30: 1-13, 2017.

MARSCHNER, H. Mineral nutrition of higher plants. 3. ed. New York, Academic Press. 2011. 672 p.

NOBRE, D. A. C. et al. Qualidade da semente do gergelim preto (Sesamum indicum L.) em diferentes épocas de colheita. Revista Brasileira de Plantas Medicinais, 15: 609-616, 2013.

NOVAIS, R. F.; NEVES, J. C. L.; BARROS, N. F. Ensaio em ambiente controlado. In: Oliveira, A. J. (Ed.) Métodos de pesquisa em fertilidade do solo. Brasília: Embrapa-SEA, 1991. cap. 12, p. 189-253.

RICHARDS, L. A. Diagnosis and improvement of saline and alkali soils. Washington: U.S, Department of Agriculture. 1954. 160 p.

SILVA, J. L. A. et al. Uso de águas salinas como alternativa na irrigação e produção de forragem no semiárido nordestino. Revista Brasileira de Engenharia Agrícola e Ambiental, 18: 66-72, 2014.

SILVA, L. C. et al. Um método simples para se estimar área foliar de plantas de gergelim (Sesamum indicum L.). Revista de Oleaginosas e Fibrosas, 6: 491-496, 2002.

SILVA, S. S. et al. Gas exchanges and production of watermelon plant under salinity management and nitrogen fertilization. Pesquisa Agropecuária Tropical, 49: e54822, 2019.

SOARES, L. A. A. et al. Growth and fiber quality of colored cotton under salinity management strategies. Revista Brasileira de Engenharia Agrícola e Ambiental, 22: 332-337, 2018 a. 
SOARES, L. A. A. et al. Physiology and production of naturally-colored cotton under irrigation strategies using salinized water. Pesquisa Agropecuária Brasileira, 53: 746-755, 2018b.

SOUSA, G .G. et al. Estresse salino em plantas de feijão-caupi em solo com fertilizantes orgânicos. RevistaAgro@mbiente On-line, 8: 359-367, 2014.

TEIXEIRA, P. C. et al. Manual de métodos de análise de solo. 3. ed. Brasília, DF: Embrapa, 2017. $573 \mathrm{p}$.

TERCEIRO NETO, C. P. C. et al. Crescimento do meloeiro 'pele de sapo' irrigado com água salobra com diferentes estratégias de manejo. Revista Caatinga, 27: 87-100, 2014.

TERCEIRO NETO, C. P. C. et al. Produtividade e qualidade de melão sob manejo com água de salinidade crescente. Pesquisa Agropecuária Tropical, 43: 354-362, 2013. 